\title{
DI SEBALIK KRISIS KEWANGAN NEGERI-NEGERI MELAYU BERSEKUTU, 1920-1924
}

\section{THE OTHER SIDE OF THE FEDERATED MALAY STATES FINANCIAL CRISIS, 1920-1924}

\section{Mohd Shazwan Mokhtar}

Pusat Kajian Sejarah, Politik dan Hal Ehwal Antarabangsa, Universiti Kebangsaan Malaysia, Selangor, MALAYSIA

Email:msm@ukm.edu.my

Published online: 20 November 2019

To cite this article: Mohd Shazwan Mokhtar. 2019. Di sebalik krisis kewangan Negeri-Negeri Melayu Bersekutu, 1920-1924. Kajian Malaysia 37(2): 95-119. https://doi.org/10.21315/km2019.37.2.5

To link to this article: https://doi.org/10.21315/km2019.37.2.5

\begin{abstract}
ABSTRAK
Artikel ini bertujuan mengkaji krisis kewangan Negeri-Negeri Melayu Bersekutu (NNMB) yang berlaku antara tahun 1920 hingga 1924. Pembentukan NNMB dan Majlis Mesyuarat Persekutuan (MMP) telah membolehkan kerajaan British menguasai pentadbiran kewangan persekutuan menerusi Pesuruhjaya Tinggi British di Tanah Melayu. Penguasaan pentadbiran kewangan ini bermatlamat untuk mengabsahkan segala sumbangan kewangan dari NNMB kepada kerajaan British. Walaupun begitu, pada akhir tahun 1920 pentadbiran kewangan British di NNMB tercabar apabila berlakunya penyusutan lebihan baki kewangan persekutuan. Krisis bertambah serius apabila kerajaan NNMB tidak mempunyai baki wang tunai pada akhir tahun 1921. Pengkaji-pengkaji awal lebih bersetuju faktor pemusatan pentadbiran kewangan oleh kerajaan NNMB antara tahun 1913 hingga 1919 merupakan sebab utama berlakunya krisis kewangan ini. Bertentangan dengan itu, bukti yang diperoleh daripada rekod kewangan dan pentadbiran NNMB, Prosiding MMP, Laporan Suruhanjaya Penghematan, CO 717 dan FCO 141 membuktikan berlakunya pertumbuhan lebihan baki kewangan sebelum tahun 1920. Bagi menyelesaikan masalah tersebut, objektif artikel ini ialah menilai semula faktor krisis kewangan NNMB. Hasil kajian membuktikan bahawa, pemusatan pentadbiran kewangan bukanlah faktor sebenar yang menyebabkan krisis kewangan NNMB. Terdapat bukti kukuh yang menunjukkan faktor kegagalan Laurence N. Guillemard selaku Pesuruhjaya Tinggi British memahami akaun kerajaan NNMB menyebabkan krisis kewangan.
\end{abstract}

(C) Penerbit Universiti Sains Malaysia, 2019. This work is licensed under the terms of the Creative Commons Attribution (CC BY) (http://creativecommons.org/licenses/by/4.0/). 
Walaupun begitu, langkah penyelesaian oleh Guillemard sejak tahun 1922 berjaya menyelesaikan krisis kewangan NNMB apabila berlakunya pertumbuhan lebihan baki kewangan NNMB yang mendadak pada tahun 1924. Justeru, artikel ini berhujah pemusatan pentadbiran kewangan bukanlah faktor utama krisis kewangan yang berlaku di NNMB antara tahun 1920 hingga 1924.

Kata kunci: sejarah ekonomi, pentadbiran British, ekonomi imperial, Tanah Melayu

\begin{abstract}
This article aims to study the Federated Malay States' (FMS) financial crisis which occurred between the year 1920 and 1924. The formation of the FMS and the Federal Council (FC) allowed the British government to control the federal financial administration through the British High Commissioner. This financial administration aimed to legalise all financial contributions from FMS to the British government. However, by the end of 1920, the British financial administration in FMS faced a deficit problem in the federal financial balances. The crisis grew serious after the FMS Government had no cash balance by the end of 1921. The early researchers concurred that the over-centralisation of the financial administration by FMS government between 1913 and 1919 was the main reason for the financial crisis. Contrary to that, the evidence obtained from the FMS financial and administrative records, the FC Proceedings, the Retrenchment Commission Report, CO 717 and FCO 141 documents showed a growing financial surplus before the year 1920. In order to resolve this problem, the objective of the article is to re-evaluate the FMS financial crisis factor. The findings show that the over-centralisation of the administration of finance was not the real factor that caused the FMS financial crisis. There is strong evidence showing that the failure of Laurence N. Guillemard as the British High Commissioner to understand FMS government's account led to the financial crisis. Nevertheless, the solution by Guillemard since 1922 has solved the FMS's financial crisis due to the rapidly growing FMS financial surplus in 1924. Hence, this article argues that the overcentralisation of finance was not the main reason for the FMS financial crisis between the year 1920 and 1924 .
\end{abstract}

Keywords: economic history, British administration, imperial economy, Malay States 


\section{PENGENALAN}

Negeri-Negeri Melayu Bersekutu(NNMB) secara sah dibentuk menerusi Perjanjian Persekutuan 1895 antara Sir C.B.H. Mitchell, Gabenor Negeri-Negeri Selat (NNS) yang juga wakil kerajaan Baginda Ratu England yang juga Maharani India dengan Raja-Raja Melayu bagi negeri Perak, Selangor, Pahang dan Negeri Sembilan (lihat lampiran). ${ }^{1}$ Menerusi perjanjian ini Raja-Raja Melayu bersetuju untuk membentuk kerajaan persekutuan yang ditadbir oleh British. Sebagai ejen dan wakil kerajaan Baginda Ratu England, Residen Jeneral merupakan ketua pentadbir di peringkat persekutuan yang bertanggungjawab terus di bawah Pesuruhjaya Tinggi British di Tanah Melayu yang juga merupakan Gabenor NNS. Setelah persekutuan NNMB dirasmikan pada tahun 1896, Kuala Lumpur telah dijadikan pusat pentadbiran persekutuan oleh British (Swettenham 1906, 275). Walaupun NNMB berstatus negeri-negeri naungan British, dari sudut pentadbirannya Pejabat Tanah Jajahan British di London mempunyai kawalan terhadapnya menerusi Pesuruhjaya Tinggi British di Tanah Melayu yang juga merupakan Presiden bagi Majlis Mesyuarat Persekutuan(MMP). Namun begitu, bagi memelihara kedudukan Raja-Raja Melayu sebagai ketua negeri, British menggunakan terma "menasihatkan" berbanding "mengarahkan" dalam menguruskan pentadbiran persekutuan. Berdasarkan terma ini, secara teknikalnya kerajaan persekutuan dan kerajaan negeri tidak tertakluk dengan setiap undang-undang kolonial yang dikeluarkan Pejabat Tanah Jajahan, melainkan kerajaan persekutuan dan kerajaan negeri ingin melaksanakannya secara sukarela. Oleh sebab itu, British menubuhkan MMP sebagai alat kawalan yang sah untuk mengawal dan menguasai pentadbiran kewangan NNMB di peringkat persekutuan. Segala dasar dan tindakan British yang dipengaruhi Pejabat Tanah Jajahan British diabsahkan menerusi enakmen yang diluluskan MMP.

Walaupun boleh dikatakan tiada kajian khusus yang menganalisis aspek pentadbiran kewangan British di NNMB, terdapat sejarawan yang menyentuh isu krisis kewangan yang berlaku di NNMB antara tahun 1920 hingga 1924. Isu ini mendapat perhatian dalam kajian Yeo (1971), Emerson (1974), Ghosh (1977) dan Ahmad Kamal (1999) yang terbatas dalam kerangka sejarah pentadbiran dan politik British di NNMB. Hasil kajian lepas ini mendapati krisis kewangan NNMB berlaku disebabkan faktor pentadbiran kewangan terpusat dan perbelanjaan yang boros oleh British. Krisis kewangan berlaku apabila pentadbiran British di peringkat persekutuan NNMB memperuntukkan belanjawan yang tinggi untuk pembangunan landasan keretapi, jalan raya, limbungan di Prai, Pulau Pinang dan pembangunan Tambak Johor. Sehingga tahun 1922, kerajaan NNMB terpaksa menampung $\$ 45.75$ juta untuk membiayai projek pembangunan yang mewah, sedangkan lebihan wang yang dimiliki oleh kerajaan NNMB hanya berjumlah \$7 juta (Ghosh 1977, 158; Yeo 1971, 94). Ironinya beban masalah perbelanjaan mewah yang berlaku ketika pentadbiran Sir Laurence Nunns Guillemard sebagai Pesuruhjaya 
Tinggi British (1920-1927) diletakkan kepada pentadbiran Sir Arthur Henderson Young (1911-1920) yang mentadbir sebelum Guillemard. Ahmad Kamal (1999) bersetuju dengan hujahan ini dengan alasan ketidakcekapan pentadbiran Young dan juga Edward Brockman (Ketua Setiausaha NNMB, 1911-1920) yang telalu bergantung dengan lebihan baki kewangan untuk membiayai pembangunan menyebabkan kerajaan NNMB mengalami defisit kewangan pada akhir tahun 1920. Kecenderungan pengkaji-pengkaji awal bersetuju dengan faktor ini adalah berdasarkan alasan yang sama diutarakan Guillemard kepada Sir Winston Churhill (Setiausaha Tanah Jajahan) bagi menjelaskan krisis kewangan yang berlaku di NNMB (FCO 141/15978). Namun, dapatan kajian awal ini diragui apabila rekodrekod kewangan NNMB bagi tahun 1911 hingga 1925 membuktikan bahawa pada akhir tahun 1919 baki kewangan NNMB adalah berjumlah $\$ 109,296,017$, sebelum menurun kepada $\$ 81,769,692$ pada tahun 1920 dan terus jatuh mendadak sebanyak 73.30\% pada tahun 1921 (Mohd Shazwan 2017, 147). Justeru, timbul persoalan mengapakah berlakunya penurunan drastik lebihan baki kewangan NNMB ini dan apakah faktor sebenar yang mempengaruhi penurunannya?

Persoalan pertama ini dijawab oleh Ghosh $(1977,84)$ yang berpandangan kemerosotan lebihan baki kewangan NNMB sejak akhir tahun 1920 adalah disebabkan tumpuan pentadbiran Guillemard yang memperuntukkan belanjawan yang tinggi terhadap pembangunan fasiliti perdagangan, jalan raya dan kesihatan bagi membolehkan sektor ekonomi eksport NNMB pulih selepas Perang Dunia Pertama. Tambahan pula, Yeo (1981) turut mendapati bahawa tindakan Guillemard melaksanakan dasar perbelanjaan wang yang besar untuk pembangunan ini turut mendapat kritikan dari dalam dan luar NNMB, khususnya Persatuan British Malaya yang berpengkalan di London. Keadaan ini seterusnya telah membawa kepada siri tuduh-menuduh antara Guillemard dengan Arthur Young dan Edward Brockman dalam mencari punca sebenar berlakunya krisis kewangan NNMB. Perbahasan ini mengukuhkan lagi keraguan, adakah benar faktor kelemahan pentadbiran Young dan Brockman yang diutarakan oleh Yeo (1971), Emerson (1974), Ghosh (1977) dan Ahmad Kamal (1999) merupakan sebab utama berlakunya krisis kewangan di NNMB antara tahun 1920 hingga 1924? Sedangkan, tumpuan terhadap pembangunan fasiliti ekonomi eksport oleh Guillemard juga adalah selaras dengan dasar ekonomi imperial yang diputuskan oleh British dalam Persidangan Ekonomi Imperial 1921. Menerusi persidangan ini British dengan jelas mengisytiharkan peranan NNMB sebagai pengeksport utama komoditi timah dan getah dalam jaringan perdagangan antara empayar British. Kebergantungan Britain terhadap bahan mentah NNMB ini adalah untuk menampung keperluan sektor perindustrian ketenteraannya yang lemah selepas tamat Perang Dunia Pertama (H.M.S.O. 1921). Meskipun begitu, penelitian terhadap kajian lepas ini masih lagi belum menjawab persoalan apakah faktor sebenar yang menyebabkan krisis kewangan di NNMB? Sehubungan itu, artikel ini cuba menjawab persoalan tersebut berdasarkan 
kerangka pentadbiran kewangan ketika pentadbiran Sir Arthur Young dan ketika pentadbiran Sir Laurence Guillemard sebagai Pesuruhjaya Tinggi British di Tanah Melayu.

\section{PENTADBIRAN KEWANGAN NNMB (1909-1919)}

Perjanjian Persekutuan 1895 tidak memberi kuasa kepada British untuk mengawal hal ehwal kewangan NNMB sehinggalah MMP ditubuhkan pada tahun 1909. British mempunyai matlamat yang jelas dalam menubuhkan MMP, iaitu untuk memberi kuasa kepada Pesuruhjaya Tinggi British di Tanah Melayu yang merupakan Presiden MMP untuk mengawal keseluruhan pentadbiran kewangan secara terpusat untuk mengumpulkan lebihan baki kewangan. Presiden MMP yang juga merupakan Pesuruhjaya Tinggi British di Tanah Melayu mempunyai kuasa untuk melantik ahli-ahli tidak rasmi MMP yang didominasi oleh pelabur dan peniaga Eropah. ${ }^{2}$ Malah, Presiden MMP turut mempunyai kuasa untuk memberi perkenan kepada setiap undang-undang yang ingin dilaksanakan oleh British (Ahmad Kamal dan Suffian 2014, 6-7). Kejayaan penubuhan MMP ini seterusnya telah membolehkan British menguasai institusi perundangan persekutuan yang mempunyai kuasa untuk mengabsahkan segala peraturan dan penggunaan kewangan NNMB. Hal ini termasuklah kerajaan negeri dikehendaki untuk mendapatkan kelulusan anggaran perbelanjaan dan pendapatannya menerusi MMP terlebih dahulu sebelum dikuatkuasakan di peringkat negeri. Hal ini bermakna segala urusan penggunaan wang kerajaan NNMB hendaklah mendapat kelulusan daripada pentadbiran Pesuruhjaya Tinggi British yang berpusat di Kuala Lumpur (Federated Malay States 1911a).

Dasar pengumpulan lebihan baki kewangan oleh British ini selaras dengan dasar ekonomi imperial yang bersifat neo-merkantilisme sejak awal abad ke-20. Dasar ekonomi imperial yang dilaksanakan oleh British mempunyai tujuan yang senyap untuk mengeksploitasi hasil keuntungan ekonomi eksport yang berasaskan timah dan getah di NNMB. Keuntungan perdagangan ini kemudiannya direkodkan sebagai lebihan baki kewangan dalam laporan kewangan tahunan NNMB. Dana ini merupakan aset kekayaan NNMB yang dikumpul dan dikawal oleh Pesuruhjaya Tinggi British menerusi MMP serta digunakan untuk kepentingan ekonomi imperial di Tanah Melayu, termasuklah pembangunan fasiliti untuk pedagang negara induk dan membiayai kos pentadbiran kolonial, khususnya membantu negeri Pahang yang dianggap miskin dalam NNMB. Dalam pada itu, prinsip pentadbiran British terhadap kewangan NNMB ialah sentiasa memastikan agar setiap perbelanjaan yang dikeluarkan oleh kerajaan NNMB hendaklah tidak melebihi jumlah pendapatan yang diperoleh (Mohd Shazwan 2017, 59-65, 140; Ghosh 1977, 39). 


\section{Pentadbiran Kewangan oleh Sir Arthur Young}

Kuasa kawalan British terhadap pentadbiran kewangan NNMB dikukuhkan lagi pada tahun 1911, iaitu ketika pentadbiran Sir Arthur Young selaku Pesuruhjaya Tinggi British di Tanah Melayu. Pentadbiran Young menggunakan MMP untuk meluluskan Enakmen Ketua Setiausaha (Perbadanan) untuk membolehkan jawatan Residen Jeneral ditukar kepada Ketua Setiausaha dalam pentadbiran British di NNMB. Ahli-Ahli Tidak Rasmi MMP membidas tindakan ini sebagai salah satu cara mengukuhkan imperialisme British di NNMB, apabila Ketua Setiausaha turut diberi kuasa untuk mentadbir lebihan kewangan NNMB. Peranan ini bertentangan dengan peranan Residen Jeneral sebelum ini yang berperanan menasihati sultan dalam hal ehwal pentadbiran (Federated Malay States 1911b). Enakmen ini memperuntukkan kuasa kepada Ketua Setiausaha untuk menggunakan materi korporat dalam urusan perdagangan seperti persetujuan kontrak dan kuasa untuk membeli bagi pihak kerajaan NNMB. Tindakan British menggunakan MMP untuk meluluskan enakmen ini sebenarnya merupakan satu langkah untuk menggabungkan pentadbiran NNMB dengan pentadbiran kolonial di NNS. Tambahan pula, bidang kuasa pentadbiran yang diperuntukkan kepada Ketua Setiausaha ini juga menunjukkan usaha British untuk menguasai pendapatan NNMB yang dimewah dengan lebihan baki kewangan yang tinggi (Mohd Shazwan, Muhammad Aslah Akmal dan Mohd. Samsudin 2017, 7).

Penggubalan dasar kewangan ketika pentadbiran Sir Arthur Young mempunyai pengaruh yang kuat daripada kerajaan imperial British yang berpusat di London. Winston Churchill, Pemerintah Pertama Admiralti bagi Tentera Laut Diraja British telah menggesa kesatuan seluruh empayar British bagi mengukuhkan supremasi maritimnya agar jaringan perdagangan antara empayar dapat dilindungi daripada ancaman musuh (Federated Malay States 1912). Berdasarkan gesaan ini, Young berjaya mempengaruhi Raja-Raja Melayu dalam MMP untuk memperuntukkan \$20 juta untuk membina kapal perang H.M.S. Malaya yang digunakan sebagai aset pertahanan British ketika Perang Dunia Pertama. Di samping itu, Young juga menggunakan alasan yang sama untuk membolehkan beliau menjadikan NNMB sebagai penyumbang terbesar dalam menampung perbelanjaan kos pertahanan empayar British ketika Perang Dunia Pertama. Kuasa kawalan kewangan yang dimiliki oleh Young membolehkan beliau menggunakan MMP untuk meluluskan bon Perbendaharaan Pinjaman Perang dan bon Perperangan Kebangsaan Britain yang berjumlah £7,616,609, serta menjadikan kerajaan NNMB sebagai penghutang dengan mengumpulkan pinjaman kewangan sebanyak $£ 2,925,532,3 s .4 d$. untuk kerajaan Britain (Federated Malay States 1919). Dasar berhutang dalam pentadbiran kewangan oleh Young ini adalah disebabkan berlakunya kemerosotan sektor perdagangan NNMB setelah British mengisytiharkan penglibatannya dalam Perang Dunia Pertama pada tahun 
1914. Peringkat awal perang, menyaksikan kerajaan NNMB tidak mampu untuk menampung kos operasi lombong timah dan menyediakan pinjaman kepada peladang getah. Justeru, pinjaman kewangan dibuat menerusi Crown Agents bagi pihak kerajaan NNMB merupakan langkah yang dilaksanakan oleh Young agar NNMB dapat memberi sumbangan kepada kerajaan Britain ketika perang. Berdasarkan komitmen kewangan ini, pentadbiran Young telah meninggalkan beban hutang yang tinggi kepada pentadbiran Sir Laurence Guillemard yang mula berkhidmat sebagai Pesuruhjaya Tinggi British pada Februari 1920.

\section{KRISIS KEWANGAN KETIKA PENTADBIRAN SIR LAURENCE GUILLEMARD}

Dasar perbelanjaan NNMB ketika pentadbiran Sir Laurence Guillemard dipengaruhi dengan dasar ekonomi imperial British selepas Perang Dunia yang digubal dalam Persidangan Ekonomi Imperial 1921. Persidangan ini telah membentuk dasar perdagangan antara empayar British yang mengikat hubungan ekonomi Britain dengan tanah jajahannya menerusi ekonomi eksport. NNMB telah dipertanggungjawabkan untuk membekalkan bahan mentah untuk sektor perindustrian Britain dan hanya memberi keutamaan terhadap produk hasil pembuatan kolonial dalam pasaran ekonomi NNMB. Pada masa yang sama, dasar ini bertujuan untuk mewujudkan peluang pekerjaan di NNMB bagi menyelesaikan masalah pengangguran di Britain (H.M.S.O. 1921). Oleh sebab itu, pentadbiran Guillemard telah memperuntukkan belanjawan yang besar untuk membangunkan fasiliti ekonomi eksport seperti landasan keretapi, jalan raya dan bekalan elektrik yang menghubungkan kawasan ladang getah dan lombong bijih timah dengan pelabuhan di NNMB serta NNS, bagi membuka peluang ekonomi kepada British.

Jadual 1 menunjukkan beban kewangan NNMB semasa pentadbiran Guillemard bagi tahun 1921 hingga 1922. Jumlah hutang yang besar terpaksa ditanggung oleh kerajaan NNMB bernilai \$22 juta untuk membayar jumlah kerugian penjualan beras kepada kerajaan NNS. ${ }^{3}$ Sejumlah $\$ 11,313,000$ pula telah disediakan oleh pentadbiran Guillemard sebagai wang pinjaman pembangunan landasan keretapi Siam antara tahun 1921 hingga 1922. Kepentingan untuk beliau meluluskan pinjaman ini adalah untuk meneruskan peranan NNMB sebagai pemiutang bagi pihak British untuk Siam yang bermula sejak tahun 1909 lagi, iaitu setelah Siam bersetuju menyerahkan negeri-negeri Melayu utara kepada British (Federated Malay States 1921b; Andaya dan Andaya 2017, 205). Di samping itu, berlakunya peningkatan perbelanjaan yang besar untuk pembangunan Pelabuhan Prai pada tahun 1922 dengan peningkatan sebanyak $31.49 \%$ berbanding tahun 1921. Pembangunan Pelabuhan Prai adalah penting bagi pentadbiran Guillemard bagi membolehkan limbungan yang dikuasai British di pelabuhan tersebut 
dapat menerima sekurang-kurangnya 6,000 tan kapal dagang yang datang dari jaringan perdagangan antarabangsanya (Federated Malay States 1920b). Selain itu, pembangunan Tambak Johor pada tahun 1922 turut menelan belanja yang besar dengan peningkatan beban kewangan sebanyak $\$ 5,022,341$ berbanding tahun 1921. Kepentingan Tambak Johor kepada British ialah bagi menggantikan penggunaan feri untuk mengangkut bekalan bahan mentah dari NNMB melalui Johor ke Singapura dengan jalan raya merentas Selat Johor. Justeru, sebagai Gabenor NNS dan Pesuruhjaya Tinggi British di Tanah Melayu, Guillemard menggunakan kuasanya sebagai Presiden MMP untuk memperuntukkan dana bagi projek pembangunan Tambak Johor bagi membolehkan bekalan bahan mentah dari NNMB untuk British dapat disalurkan ke Singapura menerusi jalan darat. ${ }^{4}$

Jadual 1: Beban kewangan kerajaan NNMB antara tahun 1921-1922

\begin{tabular}{lcc}
\hline \multicolumn{1}{c}{ Jenis hutang } & Tahun & Jumlah hutang \\
\hline $\begin{array}{l}\text { Kerugian penjualan beras yang perlu dibayar kepada } \\
\text { kerajaan Negeri-Negeri Selat }\end{array}$ & 1921 & $\$ 22$ juta \\
Pinjaman untuk Siam & 1921 & $\$ 6,428,000$ \\
& 1922 & $\$ 4,885,000$ \\
Pelabuhan Prai & 1921 & $\$ 5,703,770$ \\
& 1922 & $\$ 7,500,000$ \\
Tambak Johor & 1921 & $\$ 1,677,659$ \\
\hline
\end{tabular}

Sumber: FCO 141/15978, FMS Financial Position 1921.

Demi memenuhi permintaan Setiausaha Tanah Jajahan yang meminta lebihan baki kewangan NNMB disumbangkan kepada kerajaan Britain untuk menampung kos pertahanannya selepas Perang Dunia Pertama, Guillemard menggunakan MMP untuk meluluskan Rang Undang-Undang Pinjaman Kemenangan 1920. Enakmen ini membolehkan kerajaan NNMB mendapatkan pinjaman wang daripada penduduk Tanah Melayu bagi pihak kerajaan Britain. Dana pinjaman ini kemudiannya disalurkan ke negara induk bagi membolehkan kerajaan Britain menampung beban kewangannya selepas perang. Kesannya, individu atau firma perniagaan yang bersetuju memberikan pinjaman wang kepada kerajaan NNMB dikecualikan daripada semua jenis cukai, tetapi kerajaan NNMB terpaksa menanggung kos faedah pembayaran balik sebanyak 3\% (CO 717/1 1920; Federated Malay States 1920a). Justeru, di samping mengeluarkan perbelanjaan yang tinggi untuk pembangunan fasiliti ekonomi eksport, pentadbiran kewangan Guillemard turut menambahkan beban hutang NNMB. 
Pada peringkat awal pentadbirannya, Guillemard juga mempunyai dasar yang jelas untuk menggunakan lebihan baki kewangan NNMB untuk tujuan pembangunan selepas perang bukan sahaja di NNMB, malah tanah jajahan British yang lain. Antaranya, pada September 1920, pentadbiran Guillemard telah memperuntukkan sebanyak \$152,000 untuk menampung kos pembinaan depot imigresen di Presidensi Madras, India dan peruntukan sebanyak \$30,000 kepada Tabung Imigran India yang dikongsi bersama syarikat British Indian Steam Navigation Limited. Tujuan perbelanjaan pembangunan di luar NNMB ini adalah untuk membolehkan tenaga buruh dari India dapat disalurkan ke estet-estet getah British yang terdapat di Tanah Melayu (Federated Malay States 1920c).

Berdasarkan peruntukan belanjawan yang mewah ini, pentadbiran Guillemard dikatakan gagal mengawal aliran perbelanjaan kerajaan apabila aset kewangan persekutuan digunakan dalam jumlah yang besar dan boros (Emerson 1974, 196). Perbelanjaan besar yang telah diperuntukkan untuk pembangunan fasiliti ini akhirnya telah menyebabkan kerajaan NNMB menanggung beban kewangan yang tinggi (CO 717/1 1920). Kesannya, pada tahun 1921, pentadbiran Guillemard gagal menjelaskan $62.5 \%$ hutang pembinaan kapal H.M.S. Malaya. William George Maxwell, Ketua Setiausaha Kerajaan NNMB menjelaskan masalah ini berlaku disebabkan kerajaan NNMB tidak mampu menampung sebarang liabiliti dan terpaksa meminjam wang dalam jumlah yang besar bagi menyelesaikan hutangnya (Federated Malay States 1922e). Masalah ini seterusnya telah menjadi titik permulaan kepada krisis kewangan NNMB yang pertama semenjak akhir tahun 1920 (CO 717/25 1922).

\section{Masalah Pentadbiran Kewangan}

Pentadbiran kewangan terpusat oleh Sir Laurence Guillemard terhadap lebihan baki kewangan NNMB telah dikritik oleh Persatuan British Malaya yang berpengkalan di London kepada Setiausaha Tanah Jajahan. ${ }^{5}$ Persatuan ini mengkritik kegagalan pentadbiran Guillemard mengawal perbelanjaan lebihan baki kewangan persekutuan sehingga menyebabkan NNMB menghadapi krisis kewangan. Persatuan British Malaya mendesak agar kerajaan NNMB yang dikawal oleh Guillemard untuk menghentikan perbelanjaan yang besar. ${ }^{6}$ Sebagai reaksi bagi kritikan ini, Guillemard telah menjelaskan kepada Setiausaha Tanah Jajahan bahawa krisis kewangan yang menimpa NNMB adalah disebabkan beliau telah diberikan maklumat yang salah berkaitan kedudukan kewangan kerajaan persekutuan oleh penasihatnya. Guillemard turut menuduh ketidakcekapan pentadbiran sistem kewangan oleh pendahulu beliau yang telah menyebabkan NNMB menghadapi krisis kewangan pada tahun 1921. Bagi Guillemard dasar kewangan oleh Pesuruhjaya Tinggi British sebelumnya, iaitu Arthur Young dan bekas Ketua Setiausaha kerajaan NNMB, Edward Brockman telah menyebabkan 
kerajaan persekutuan terpaksa menanggung beban kewangan yang tinggi. Pentadbiran Young dan Brockman dituduh terlalu bergantung dengan lebihan baki kewangan kerajaan persekutuan untuk tujuan perbelanjaan pembangunan kerja raya sehingga menyebabkan NNMB tidak mempunyai lebihan baki kewangan tunai pada tahun 1920 (FCO 141/15978).

Ahmad Kamal (2006) menyokong alasan Guillemard yang menyalahkan ketidakcekapan pentadbiran kewangan Sir Arthur Young dan Edward Brockman sebagai faktor utama krisis kewangan yang dialami NNMB. Walaupun begitu, penjelasan oleh Young dan Brockman kepada Setiausaha Tanah Jajahan telah membuktikan hal sebaliknya. Young membuktikan kepada Setiausaha Tanah Jajahan bahawa sebelum persaraan beliau pada tahun 1919, NNMB tidak mempunyai sebarang komitmen hutang, sebaliknya mempunyai lebihan baki kewangan yang tinggi. Bahkan, ketika menghadapi Perang Dunia Pertama, Young telah mengarahkan kerajaan NNMB untuk menghentikan perbelanjaan untuk sebarang projek pembangunan kerja raya yang baharu. Young turut mengkritik Guillemard yang gagal memahami sistem kewangan persekutuan, khususnya akaun kerajaan NNMB sehingga menyebabkan kedudukan lebihan baki kewangan persekutuan gagal dikenal pasti pada tahun 1921 (FCO 141/15978).

Kegagalan Guillemard untuk memahami sistem kewangan oleh pendahulu beliau dikesan menerusi ketidakcekapan beliau mengenal pasti kedudukan lebihan baki kewangan NNMB pada peringkat awal pentadbirannya. Guillemard tersalah anggap dengan menyangka kerajaan persekutuan memiliki lebihan baki kewangan sebanyak \$110 juta. Keyakinan ini telah menyebabkan Guillemard meluluskan perbelanjaan yang besar untuk mengambil alih projek pembinaan landasan keretapi di Penang Hill (kini Bukit Bendera) daripada kerajaan NNS sebanyak $\$ 650,000$ yang diperuntukkan dalam anggaran perbelanjaan pada tahun 1921. Sedangkan pada tahun 1920, MMP hanya meluluskan perbelanjaan sebanyak $\$ 250,000$ untuk projek tersebut. Dalam laporan kewangan akhir pada tahun 1919 juga yang disediakan oleh Edward Brockman membuktikan bahawa, kerajaan NNMB mempunyai lebihan baki kewangan sebanyak \$109,926,017 dan sejumlah $\$ 8,226,768.71$ wang tunai pula terdapat di perbendahaan kerajaan persekutuan dan bank kerajaan (FCO 141/15978). Tambahan pula, Young turut membuktikan wujudnya perbelanjaan yang tinggi oleh Guillemard untuk menambah kakitangan awam dalam Jabatan Kesihatan dan Jabatan Kerja Raya. Pada tahun 1920, kos untuk menampung kakitangan awam bagi kedua-dua jabatan ini berjumlah $\$ 1,360,719$ dan kemudiannya meningkat sebanyak $75.18 \%$ pada tahun 1921 . Di samping itu, selaras dengan dasar Pejabat Tanah Jajahan yang mencadangkan peningkatan kadar gaji dan pencen bagi pekerja Eropah di NNMB, pentadbiran Guillemard telah meningkatkan emolumen untuk dirinya sebagai Pesuruhjaya Tinggi British dan jawatan pentadbiran lain di NNMB. Kesannya, berlaku peningkatan sebanyak $\$ 8,077$ dalam anggaran belanjawan emolumen pada tahun 1921 (CO 717/1; CO 
717/12). Dalam rumusan ringkasnya kepada Setiausaha Tanah Jajahan, Young membidas kritikan Guillemard:

The critical position in which he states the finances of the Federated Malay States now stand is not due as he asserts to "the mistakes of the past" but entirely to his own want of fore-thought, it would have been more dignified and would have been a truer statement of facts, if Sir L. Guillemard had confessed that he did not understand that the available cast balance was not sufficient to meet. (FCO 141/15978)

Kelemahan pentadbiran Guillemard sendiri dilihat oleh ahli-ahli tidak rasmi MMP sebagai faktor penting yang menyebabkan krisis kewangan di NNMB. Pentadbiran Guillemard dikritik oleh seorang ahli tidak rasmi MMP, iaitu Arthur Noel Kenion, yang berpandangan pentadbiran Guillemard terlalu bergantung dengan nasihat Ketua Setiausaha dan Penasihat Undang-undang NNMB. Oleh sebab itu, Guillemard dikatakan gagal untuk mengawal lebihan baki kewangan NNMB. Kesan kritikan ahli-ahli tidak rasmi ini telah menyebabkan Guillemard mengakui sendiri kelemahan pentadbirannya:

I came out to Malaya knowing nothing whatever of the details of finances. I had as soon as possible to learn all I could about the administration and finances of the Colony, of the Federated Malay States and of the Unfederated Malay States. I was not able to sit down at an office table and learn these things. I had to spend a good deal of my time travelling and paying ceremonial visit. (Federated Malay States 1922d)

Kenyataan Guillemard ini menjadi bukti penting bahawa kelemahan beliau untuk memahami dasar pengumpulan lebihan baki kewangan yang dilaksanakan oleh pendahulu beliau di NNMB. Alasan beliau yang terpaksa untuk hadir dalam majlis-majlis di peringkat persekutuan adalah berdasarkan peristiwa penting yang berlaku pada tahun 1921, iaitu ketibaan pelayaran kapal perang H.M.S. Malaya dari Britain yang turut dianggotai oleh Putera Arthur (Duke of Connaught) yang merupakan anakanda ketiga Ratu Victoria. Pelayaran yang membawa misi diplomasi ini juga turut menyambut kemenangan British dalam Perang Dunia Pertama dan menghargai sumbangan NNMB terhadap pembinaan H.M.S. Malaya yang digunakan ketika perang. Justeru, kerajaan NNMB yang diketuai oleh Guillemard telah berperanan untuk menyambut ketibaan Putera Arthur dengan mengadakan acara hiburan, sukan, anugerah pingat perang dan lawatan baginda di Tanah Melayu dan wilayah sekitarnya sepanjang tahun 1921. Acara sukan yang mengambil banyak masa Guillemard ialah penganjuran Piala H.M.S. Malaya sejak bulan Februari hingga September dan lawatan bagi menyampaikan pingat penghargaan perang di Tanah Melayu serta Brunei antara bulan September dan Oktober 1921. Guillemard turut terlibat dalam penganjuran Majlis Tari-Menari 
Tentera pada bulan Oktober di Singapura pada tahun yang sama. Tambahan lagi, sebagai persiapan menerima ketibaan H.M.S. Malaya, Guillemard turut mengadakan lawatan di negeri-negeri Melayu pada awal tahun 1921 dan persiapan majlis perasmian tugu Frank Swettenham yang menjadi acara penting menyambut ketibaan kapal perang tersebut. Pembinaan tugu ini adalah sebagai tanda penghargaan terhadap Swettenham sebagai Residen Jeneral British pertama di NNMB. Komitmen Guillemard yang tinggi dalam menyambut ketibaan H.M.S. Malaya ini juga telah menyebabkan Majlis Perundangan NNS menggazetkan pelantikan Mr. F.S. James sebagai Timbalan Gabenor bagi menjalankan tugas pentadbiran NNS ketika ketiadaan Guillemard.?

\section{Siasatan Suruhanjaya Penghematan}

Pada tahun 1922, pentadbiran Guillemard telah meluluskan penubuhan Suruhanjaya Penghematan (Retrenchment Commission) bagi menyiasat krisis kewangan dan menyelaraskan semula urusan perbelanjaan persekutuan (Emerson 1974, 196). Kerajaan NNMB turut berpendirian, penubuhan Suruhanjaya Penghematan penting untuk menyediakan pelan penstrukturan semula jabatan kerajaan bagi menjimatkan perbelanjaan (Federated Malay States 1922c). Justeru, bagi mencapai matlamat tersebut, Suruhanjaya Penghematan berperanan menjalankan siasatan terhadap (1) setiap operasi dan peranan badan kerajaan, (2) perbelanjaan yang dikeluarkan oleh setiap jabatan kerajaan dan (3) menyiasat setiap jenis elaun dan emolumen, tidak termasuk gaji yang diterima oleh pegawai kerajaan. Anggota suruhanjaya telah melaksanakan siasatan terhadap keseluruhan jabatan kerajaan selama 66 hari dengan melibatkan soal siasat terhadap 65 orang pegawai kerajaan. ${ }^{8}$ Soal siasat ini dilakukan untuk mendapatkan bukti dan maklum balas ketua-ketua jabatan terhadap krisis kewangan yang dihadapi kerajaan NNMB (IMR 151/1921).

Suruhanjaya Penghematan telah menyediakan 49 laporan interim yang merupakan hasil siasatan yang dilakukan dengan melibatkan jabatan kerajaan seperti Perbendaharaan NNMB, Jabatan Kereta Api serta Jabatan Perdagangan dan Kastam. Tumpuan terhadap ketiga-tiga jabatan ini adalah disebabkan fungsi Perbendaharaan NNMB yang mentadbir lebihan baki kewangan di peringkat persekutuan. Jabatan Perdagangan dan Kastam pula merupakan penyumbang utama kepada hasil pendapatan persekutuan, sementara Jabatan Kereta Api merupakan jabatan yang menerima peruntukan belanjawan yang tinggi. Bagi membolehkan siasatan yang lebih komprehensif dapat dilaksanakan, Sd. W.G. Maxwell, Ketua Setiausaha bagi kerajaan NNMB telah mengarahkan Residen British di Perak, Selangor, Negeri Sembilan dan Pahang untuk menubuhkan Jawatankuasa Penghematan untuk menyiasat bajet perbelanjaan di peringkat negeri. Langkah ini adalah untuk memastikan keberkesanan pentadbiran jabatan kerajaan persekutuan dan agensi di peringkat negeri (IMR 151/1921). 
Secara keseluruhannya, Suruhanjaya Penghematan merumuskan terdapat tiga faktor utama yang menyebabkan krisis kewangan NNMB. Pertamanya, kegagalan operasi sistem pentadbiran kerajaan. Kedua, kawalan kewangan oleh kerajaan NNMB yang tidak berkesan. Ketiga, dasar kewangan oleh kerajaan NNMB yang tidak kukuh dengan memperuntukkan belanjawan yang tinggi untuk pembangunan kerja raya. Berdasarkan rumusan ini, Suruhanjaya Penghematan telah membuktikan bahawa perbelanjaan yang melebihi dua kali ganda daripada hasil pendapatan pada tiga suku pertama tahun 1921 oleh pentadbiran Guillemard merupakan faktor utama yang menyebabkan krisis kewangan persekutuan. Tindakan berbelanja melebihi pendapatan ini telah menyebabkan kerajaan NNMB menanggung hutang yang tinggi sehingga $\$ 45.75$ juta berbanding pendapatan sebanyak \$4.5 juta pada tahun 1921. Kesannya, sehingga akhir tahun 1921 kerajaan NNMB tidak mempunyai baki wang tunai. Suruhanjaya Penghematan menilai tanggungan hutang yang tinggi oleh kerajaan NNMB ini sebagai satu bentuk kegagalan pentadbiran kewangan terpusat oleh Guillemard selaku Pesuruhjaya Tinggi British di Tanah Melayu. Tambahan pula, penelitian terhadap laporan Siasatan Penghematan juga membuktikan bahawa isu pentadbiran kewangan terpusat oleh pentadbir sebelum Guillemard bukanlah faktor yang menyebabkan krisis kewangan di NNMB. Laporan Siasatan Penghematan jelas memetik pembuktian oleh Mr. Frost, Pemangku Pegawai Daerah Kinta pada tahun 1922 yang menyatakan sistem pentadbiran kewangan terpusat yang dilaksanakan adalah efisien selaras dengan standard sistem pentadbiran di Eropah. Walaupun begitu, tindakan British yang mengutamakan penjawat awam Eropah sebenarnya merupakan faktor yang membebankan kewangan NNMB (HCO 545/1922). ${ }^{9}$

Suruhanjaya Penghematan turut mendapati bahawa tindakan pentadbiran Guillemard yang bergantung dengan pinjaman kewangan Sterling dalam pasaran London tidak menyelesaikan krisis kewangan yang dihadapi kerajaan NNMB. Kuasa pentadbiran kewangan yang diperuntukkan kepada Pesuruhjaya Tinggi British di Tanah Melayu oleh MMP membolehkan Guillemard mendapatkan pinjaman kewangan untuk kerajaan NNMB tanpa sebarang sekatan. Justeru, sehingga bulan Januari 1922, Crown Agent telah menyediakan pinjaman kewangan sehingga $£ 4,830,000 .{ }^{10}$ Sejumlah $£ 3,890,000$ daripada jumlah pinjaman ini telah digunakan oleh kerajaan NNMB untuk membayar hutangnya dalam bentuk overdraf. ${ }^{11}$ Baki berjumlah $£ 940,000$ digunakan untuk menampung defisit perbelanjaan kerajaan NNMB. Keadaan ini sebenarnya tidak menyelesaikan krisis kewangan yang dihadapi oleh kerajaan NNMB, malah menambahkan lagi beban hutang persekutuan kerana beban kadar faedah yang ditetapkan oleh Crown Agent tidak mampu ditanggung oleh kerajaan NNMB (HCO 545/1922). 
Jadual 2: Jumlah overdraf dan hutang kerajaan NNMB sehingga tahun 1922

\begin{tabular}{lc}
\hline Institusi & Jumlah \\
\hline Bayaran overdraf untuk Crown Agent & $£ 1,940,000$ \\
Overdraf Chartered Bank & $£ 650,000$ \\
Pinjaman overdraf Negeri-Negeri Selat & $£ 300,000$ \\
Ansuran hutang beras kepada Negeri-Negeri Selat & $£ 700,000$ \\
Pinjaman kepada Siam, Januari 1922 & $£ 300,000$ \\
\hline Jumlah & $£ 3,890,000$ \\
\hline
\end{tabular}

Sumber: HCO 545/1922

Jadual 2 memaparkan jumlah overdraf yang diperoleh Ketua Setiausaha kerajaan NNMB sehingga tahun 1922. Bayaran yang tinggi untuk Crown Agent yang bernilai $£ 1,940,00$ ini adalah disebabkan dasar ekonomi imperial British yang menetapkan agar segala pembelian barangan keperluan untuk pembangunan perlu dibeli menerusi Crown Agent. Dasar ini sebenarnya merupakan satu bentuk eksploitasi kewangan oleh British di NNMB menerusi monopoli terhadap tender atau sebut harga bagi pihak kerajaan persekutuan. ${ }^{12}$ Data ini juga menunjukkan bahawa kerajaan NNMB perlu mendapatkan overdraf untuk melangsaikan hutangnya dengan kerajaan NNS yang bernilai $£ 1$ juta. Sebanyak $£ 300,000$ pula merupakan overdraf untuk dipinjamkan kepada Siam. Perbelanjaan yang tinggi bagi dana pinjaman untuk Siam ini merupakan usaha British untuk menggabungkan jaringan landasan keretapi dari Siam ke Singapura merentasi NNMB (Emerson 1974, 196). Tambahan pula, usaha ini juga merupakan satu bentuk strategi imperialisme British untuk membendung pengaruh Jerman sejak era Perang Dunia Pertama di Siam yang mengancam kedudukan kuasa imperialnya di Semenanjung Tanah Melayu (CO 717/13).

Bagi krisis kewangan ini, Suruhanjaya Penghematan telah mendesak agar kerajaan NNMB menghentikan perbelanjaan mewah bagi projek-projek pembangunannya. Antaranya, projek pembangunan landasan keretapi yang menghubungkan Siam ke Singapura yang dianggap membazir serta projek pembangunan serentak Pelabuhan Prai dan Tambak Johor yang dipertikaikan nilai ekonominya (HCO 545/1922). Walaupun kerajaan NNMB telah menerima cadangan penjimatan perbelanjaan oleh Suruhanjaya Penghematan, kerajaan persekutuan tetap meneruskan usaha pembangunan keretapi dan pelabuhan berdasarkan alasan untuk melindungi kepentingan aktiviti perdagangan kolonial British di NNS (Federated Malay States 1922b). 


\section{LANGKAH MENGATASI KRISIS KEWANGAN NNMB}

Bagi mengatasi krisis kewangan NNMB, Suruhanjaya Penghematan menggesa agar pentadbiran Guillemard menghentikan kesemua urusan perbelanjaan yang mewah untuk tujuan pembangunan. Gesaan ini berdasarkan hujahan oleh pihak suruhanjaya bahawa, walaupun pihak kerajaan NNMB melaksanakan kawalan terhadap aktiviti ekonomi yang ketat tanpa pengurangan perbelanjaan, masalah krisis kewangan persekutuan tidak akan selesai (HCO 545/1922). Berdasarkan gesaan ini, Guillemard telah menggariskan tiga langkah utama untuk mengatasi krisis kewangan persekutuan. Pertama, melaksanakan langkah mengurangkan perbelanjaan serendah yang mungkin dalam setiap projek pembangunan NNMB. Kedua, melakukan pinjaman untuk NNMB menampung kos projek pembangunan. Ketiga, memulihkan kembali sistem perbendaharaan persekutuan (FCO 141/15978).

Dasar pengurangan perbelanjaan oleh Guillemard dilaksanakan dengan memastikan kerajaan persekutuan tidak mengeluarkan perbelanjaan yang tinggi untuk menampung sebarang usaha pembangunan yang tidak menguntungkan dalam jangka masa pendek. Walaupun begitu, projek pembangunan landasan keretapi yang merupakan nadi aktiviti perdagangan persekutuan telah dilaksanakan sejak tahun 1920 tetap terus dilaksanakan untuk memastikan setiap aset kerajaan NNMB dapat dipelihara daripada menjadi projek terbiar. ${ }^{13}$ Di samping itu, langkah penjimatan tetap dilakukan terhadap anggaran perbelanjaan pembangunan keretapi pada tahun 1922 dengan pengurangan bajet pembinaan landasan keretapi kepada \$39 juta berbanding anggaran awalnya pada tahun 1921 dengan anggaran bajet bernilai \$60 juta (Federated Malay States 1922a). Keperluan untuk kerajaan NNMB meneruskan usaha pembangunan landasan keretapi yang melibatkan negeri-negeri di luar persekutuan adalah demi kepentingan ekonomi imperial British di NNMB (Federated Malay States 1922b). Jaringan landasan keretapi ini menghubungkan kawasan-kawasan industri NNMB dengan pelabuhan empayar British yang penting di Singapura dan Port Swettenham. Tambahan pula, Ketua Setiausaha kerajaan NNMB turut menegaskan adalah mustahil bagi pihak kerajaan persekutuan untuk memberhentikan projek pembangunan landasan keretapi yang menghubungkan jaringan perhubungan antara Pahang dengan Kelantan dan Singgora (Siam) dengan Golok. Sekiranya projek pembangunan landasan keretapi berskala besar ini dihentikan, ia akan menyebabkan kerajaan NNMB terpaksa menanggung kerugian yang tinggi (Federated Malay States 1922c). ${ }^{14}$

Guillemard turut melaksanakan usaha pinjaman kewangan bagi mengatasi masalah desifit kewangan yang dialami pentadbirannya dengan menggunakan MMP untuk meluluskan Straits Settlements Loan Enactment, 1921 (Federated Malay States 1922a). Walaupun mendapat kritikan daripada ahli-ahli tidak rasmi MMP seperti Mr. Kenion dan Mr. Kindersley yang mempersoalkan keperluan 
kerajaan persekutuan untuk melakukan pinjaman kewangan menerusi NNS, enakmen ini tetap diluluskan MMP. Faktor kelemahan undian daripada ahli-ahli tidak rasmi yang diatasi oleh majoriti pegawai British dalam MMP dan juga faktor kelemahan kewangan kerajaan persekutuan menyebabkan ahli-ahli tidak rasmi terpaksa bersetuju dengan usaha pinjaman kewangan oleh Guillemard (Federated Malay States 1921a).

Straits Settlements Loan Enactment, 1921 yang mengandungi dua rang undang-undang pinjaman kewangan, merupakan penyelesaian oleh Guillemard untuk mengukuhkan kembali kedudukan kewangan persekutuan yang terjejas sejak akhir tahun 1920. Pertama, rang undang-undang untuk memberikan Ketua Setiausaha kerajaan NNMB mendapatkan pinjaman dengan tidak melebihi $\$ 15,000,000$ dengan kadar faedah sebanyak 7\% daripada kerajaan NNS (Federated Malay States 1921a). Bagi mencapai matlamat ini, British telah menggunakan Majlis Perundangan NNS untuk meluluskan pinjaman kewangan NNMB di bawah peruntukan Ordinan Pinjaman 1921, dengan menetapkan syarat kadar faedah 7\% hendaklah dibayar pada bulan Mei dan November dalam tempoh lima tahun. ${ }^{15}$ Ahmad Kamal (2006) berpandangan usaha untuk mendapatkan pinjaman dari NNS ini adalah untuk menjelaskan hutang awam NNMB. Namun, apabila diteliti kembali penjelasan Ketua Setiausaha kerajaan NNMB, pinjaman wang sejumlah $\$ 15,000,000$ ini adalah untuk menebus hutang kerajaan NNMB pada tahun 1916 yang digunakan sebagai sumbangan untuk kerajaan imperial British bagi menghadapi Perang Dunia Pertama (Federated Malay States 1921a).

Rang undang-undang pinjaman yang kedua pula berkaitan pinjaman kerajaan NNMB berjumlah $£ 10,000,000$ yang diperoleh dalam pasaran saham kolonial (colonial stock) menerusi Akta Stok Kolonial 1900 yang merupakan satu bentuk dasar neo-merkantilisme Pejabat Tanah Jajahan British yang penting pada awal abad ke-20. ${ }^{16}$ Akta ini menjamin hubungan perniagaan antara Britain sebagai negara induk dengan tanah jajahan menerusi kadar faedah pinjaman lebih murah berbanding pinjaman secara terus dalam pasaran London. Walaupun begitu, peruntukan Akta Stok Kolonial 1900 hanya memperuntukkan kelayakan terhadap tanah jajahan mahkota dan "dominion" British yang boleh menjadi pemegang amanah saham kolonial (Sunderland 2013, 27). Justeru, sebagai negeri naungan British, NNMB tidak layak untuk memohon pinjaman menerusi Akta Stok Kolonial 1900, memandangkan kedudukannya yang tidak diiktiraf oleh Perbendaharaan Britain sebagai pemegang sekuriti dalam saham kolonial. ${ }^{17}$ Tambahan pula, penggubalan Akta Stok Kolonial 1900 ini sebenarnya adalah untuk menggalakkan pelaburan empayar British di seluruh "dominion" dengan menyediakan perkhidmatan pinjaman kewangan dengan faedah yang murah (Cain dan Hopkins 2014, 229). Asas penggubalan Akta Stok Kolonial ini secara tidak langsung menolak hujahan kemungkinan sebab penolakan Perbendaharaan Britain terhadap pinjaman kewangan $£ 10,000,000$ oleh kerajaan NNMB. ${ }^{18}$ Oleh sebab 
itu, pinjaman ini dilakukan dengan naungan kerajaan NNS sebagai pemegang amanah. ${ }^{19}$ Akhirnya pada akhir tahun 1921, kerajaan Britain telah meluluskan pinjaman $£ 10,000,000$ untuk NNMB melalui kerajaan NNS dengan pembayaran ansuran awal sebanyak $£ 5,155,000$ pada bulan Disember dengan kadar faedah sebanyak 6\%. Bayaran seterusnya dilakukan pada Mei 1922 yang berjumlah $£ 4,200,000$ dengan kadar feadah sebanyak 4.5\% dan seterusnya baki $£ 645,000$ telah dibayar pada bulan Ogos dalam tahun tersebut (Federated Malay States 1922c). Wang ini digunakan oleh pentadbiran Guillemard untuk menstruktur semula akaun kewangan kerajaan NNMB yang tidak seimbang dengan melibatkan beban hutang yang tinggi untuk pembangunan Jabatan Kereta Api dan Jabatan Kerja Raya. $^{20}$

\section{Kedudukan Lebihan Baki Kewangan NNMB, 1920-1925}

Rajah 1 menunjukkan lebihan baki kewangan yang dimiliki kerajaan NNMB sejak tahun 1920 hingga tahun 1925. Peruntukan perbelanjaan yang besar sejak akhir tahun 1920 telah menyebabkan berlakunya kemerosotan mendadak lebihan baki kewangan NNMB sebanyak \$59,936,977 berbanding $\$ 81,769,692$ pada tahun 1920 dengan desifit kewangan yang bernilai $\$ 59,936,978$. Krisis ini berlaku apabila nilai perbelanjaan kerajaan NNMB pada tahun 1920 lebih tinggi, iaitu sebanyak $\$ 100,433,471$ berbanding pendapatan yang diperoleh dengan hanya sebanyak $\$ 72,277,146$. Sementara itu, pada tahun 1921, pendapatan kerajaan NNMB hanya bernilai $\$ 54,449,568$ sedangkan perbelanjaan yang dikeluarkan lebih tinggi dengan nilai $\$ 59,936,978$ (Federated Malay States 1926.) Setelah langkah penjimatan perbelanjaan dilaksanakan pada tahun 1922 berlakunya peningkatan lebihan baki kewangan NNMB sebanyak $12.29 \%$ berbanding tahun 1921. Pertumbuhan perlahan pada tahun 1922 ini juga disebabkan hanya selepas bulan September 1922, keadaan ekonomi persekutuan mula menunjukkan tanda positif (H.C.O. Ch. Sec. 798/1922). Pengukuhan lebihan baki kewangan NNMB hanya berlaku sejak tahun 1923 apabila kerajaan NNMB mula melaksanakan langkah pinjaman kewangan dan penstrukturan semula pentadbiran ekonomi di peringkat persekutuan. Peningkatan sebanyak $\$ 16,554,173$ atau $46.45 \%$ pula dicatatkan pada tahun 1924 yang merupakan tahun peningkatan mendadak bagi prestasi kewangan NNMB secara keseluruhannya (Federated Malay States 1925). 


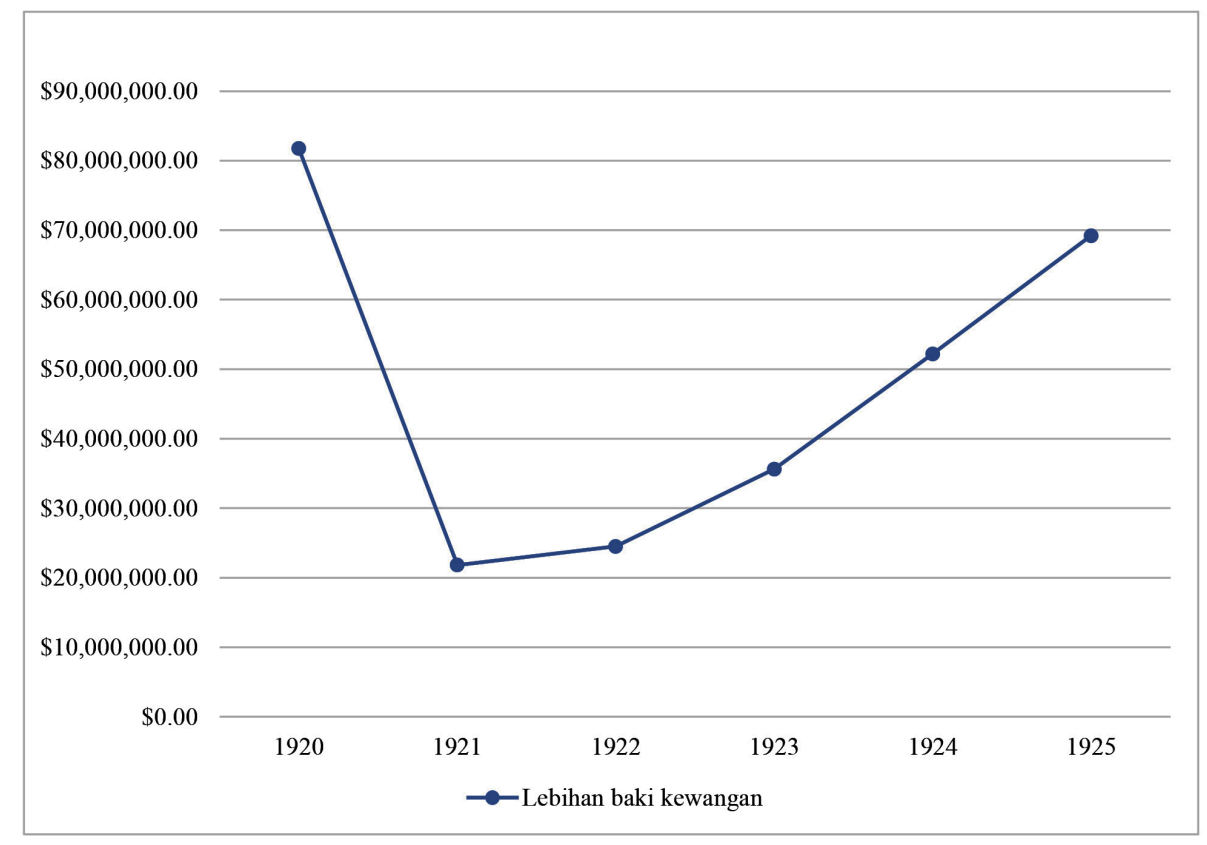

Rajah 1: Nilai lebihan baki kewangan NNMB, 1920-1925

Sumber: Federated Malay States Annual Report for Year 1920-1925.

\section{KESIMPULAN}

Pentadbiran kewangan terpusat di NNMB merupakan satu bentuk imperialisme ekonomi oleh British yang bertujuan untuk mengawal aset kewangan NNMB yang digunakan bagi kepentingan ekonominya. Matlamat ini terbukti menerusi pembentukan MMP pada tahun 1909 oleh Sir John Anderson yang memberi kuasa kepada Pesuruhjaya Tinggi British di Tanah Melayu untuk mengawal keseluruhan pentadbiran kewangan NNMB di peringkat pusat. Rekod-rekod kewangan NNMB telah membuktikan wujudnya sumbangan kewangan yang tinggi dari NNMB kepada Britain, terutamanya pada era Perang Dunia Pertama. Walaupun begitu, prinsip berbelanja dengan tidak melebihi pendapatan tetap dipatuhi bagi memastikan lebihan kewangan NNMB tetap terjamin. Namun, krisis kewangan mula berlaku sejak akhir tahun 1920 hingga 1924, iaitu sejak Sir Laurence N. Guillemard bertugas sebagai Pesuruhjaya Tinggi British. Akibat tidak memahami rekod akaun yang ditinggalkan oleh pentadbiran sebelum beliau, Guillemard cenderung untuk meluluskan belanjawan pembangunan yang mewah bagi memenuhi dasar ekonomi imperial British sehingga menyebabkan kerajaan NNMB menanggung hutang yang tinggi. Isu ini sebenarnya diakui oleh Guillemard sendiri dalam persidangan MMP 
pada tahun 1922. Namun demikian, pentadbiran Guillemard berjaya menangani krisis kewangan ini daripada berlarutan apabila berjaya meningkatkan lebihan baki kewangan NNMB pada tahap yang tinggi pada tahun 1925. Di samping itu, walaupun pentadbiran Guillemard mula melaksanakan dasar disentralisasi yang memulihkan semula kuasa pentadbiran Majlis Mesyuarat Negeri, institusi MMP tetap dikekalkan. Perjanjian Pembentukan Semula MMP 1927, telah memberi peluang kepada British untuk mengukuhkan lagi penguasaannya terhadap pentadbiran kewangan NNMB, apabila setiap anggaran perbelanjaan di peringkat negeri hendaklah diluluskan oleh MMP melalui resolusi atau Enakmen Perbekalan yang dikeluarkan (Ahmad Kamal dan Suffian 2014, 15).

\section{PENGHARGAAN}

Makalah ini merupakan hasil penyelidikan di bawah Geran Universiti Kebangsaan Malaysia Fellowship Scheme (UKM PDF/238/2/3).

\section{NOTA}

1. Penulis berhujah, tahun pembentukan NNMB adalah pada tahun 1895, iaitu ketika Perjanjian Persekutuan 1895 dimeterai. Hujahan ini dibuktikan menerusi laporan tahunan NNMB yang jelas menyatakan Perjanjian Persekutuan 1895 membentuk persekutuan yang kemudiannya dikenali sebagai NNMB (Federated Malay States 1922). Hujahan ini dikukuhkan lagi dengan penjelasan WS Gibson, Penasihat Undang-Undang NNMB pada tahun 1932, Perjanjian Persekutuan 1895 telah membentuk NNMB, persekutuan tidak dapat dibentuk tanpa punca kuasa yang diperuntukkan dalam klausa kelima Perjanjian Persekutuan 1985. Tahun 1896 yang dipersetujui dalam penulisan Andaya dan Andaya (2017), Ghosh (1977) dan Ahmad Kamal (1999) sebenarnya merupakan tahun NNMB dirasmikan setelah mengalami proses pembentukan sistem pentadbiran persekutuan. Walaupun jawatan Residen Jeneral turut dirasmikan pada tahun 1896, jawatan tersebut terlebih dahulu telah wujud pada tahun 1895, iaitu sebaik sahaja Perjanjian Persekutuan 1895 dipersetujui oleh Raja-Raja Melayu (FCO 141/16275, 1932).

2. Ketika ketiadaan Pesuruhjaya Tinggi British, Ketua Setiausaha akan berperanan sebagai presiden dalam persidangan MMP. Ahli-ahli tidak rasmi MMP yang kebiasaannya terdiri daripada wakil firma Eropah, wakil tauke Cina dan Dewan Perniagaan dicalonkan oleh Pesuruhjaya Tinggi British yang kemudiannya diluluskan keahlian mereka dalam MMP (Federated Malay States 1911a).

3. Isu ini merujuk kepada krisis bekalan beras yang dihadapi Tanah Melayu selepas Perang Dunia Pertama. Keadaan ini telah menyebabkan kerajaan NNMB terpaksa membeli bekalan beras daripada pasaran Saigon dengan harga yang tinggi. Oleh itu, British telah menggunakan dana daripada kerajaan NNS, kerajaan Johor dan 
kerajaan NNMB untuk mendapatkan import bekalan beras tersebut. Lihat Lim (1977, 120-131).

4. Alvin Chua, The Causeway, National Library Board, Singapore, 2004. http://eresources.nlb.gov.sg/infopedia/articles/SIP_99_2004-12-30.html (diakses pada 19 Ogos 2017).

5. Pada tahun 1920, golongan pemodal dan peniaga British telah menubuhkan Persatuan British Malaya di London. Persatuan ini berperanan untuk melindungi kepentingan ekonomi ahlinya termasuklah dalam urusan aliran kemasukan modal di Tanah Melayu. Aktiviti perdagangan merkantilisme di NNMB turut bergantung dengan Persatuan British Malaya untuk memastikan ekonomi eksportnya dapat tumbuh dengan pesat, malah menerusi modal daripada persatuan ini pembangunan fasiliti perdagangan dapat dilakukan oleh pihak kerajaan NNMB. Association of British Malaya, The Singapore Free Press and Mercantile Advertiser, 31 August 1920. Lihat juga, Association of British Malaya, The Straits Times, 19 November 1920.

6. Shorthand Report of the Proceedings of the Federal Council, 1924. Correspondence from the Association of British Malaya, London, 27 July 1923.

7. Federated Malay States Annual Report for the Year 1921, hlm. 21-22; His Majesty's Battleship Malaya, The Straits Times, 13 January 1921; Swettenham Statue, Malaya Tribune, 22 January 1921; H.M.S. Malaya Cup, Malaya Tribune, 19 September 1921; Ceremonies at Brunei, The Straits Times, 26 October 1921; Military Ball, Malaya Tribune, 27 October 1921; The Singapore Free Press and Mercantile Advertiser, 12 February 1921.

8. Anggota Suruhanjaya Penghematan yang dilantik Pesuruhjaya Tinggi British di Tanah Melayu ialah William Sumner Gibson (Penasihat Undang-Undang NNMB), John Henry Mattews (Ahli Tidak Rasmi MMP), Dugan Homfray Hampshire (Ahli Tidak Rasmi MMP), George Preston Bradney (Auditor NNMB), Eric Ayton Dickson (Malayan Civil Service) dan Tetuan John Archibald Russell (J.A. Russell \& Co.) HCO 545/1922.

9. Suruhanjaya Penghematan berpandangan bahawa tumpuan pentadbiran Guillemard menerima perkhidmatan penjawat awam Eropah menyebabkan kerajaan NNMB terpaksa menampung belanjawan emolumen yang tinggi, khususnya bayaran elaun. Pihak suruhanjaya mendapati peruntukkan $\$ 1,405,000$ pada tahun 1922 untuk elaun keseluruhan penjawat awam Eropah oleh pentadbiran Guillemard merupakan satu bentuk kegagalan pentadbiran kewangan kerana melebihi anggaran belanjawan. Tambahan lagi, peruntukan elaun bagi kadar gaji yang tinggi untuk penjawat awam Eropah di NNMB bertentangan dengan perkhidmatan awam di Britain yang tidak menerima bonus dan elaun bagi pegawai British dengan gaji £2,000 (HCO 545/1922).

10. Crown Agent ialah ejen kerajaan Britain yang telah ditubuhkan sejak tahun 1700an yang menerima geran daripada Perbendaharaan Britain. Berperanan untuk merekrut pekerja dan urusan perbekalan di tanah jajahan. Pada tahun 1833, kerajaan Britain telah melantik George Baillie dan Edward Barnard sebagai Joint Agent General untuk tanah jajahan mahkota yang pertama. Mereka telah diberikan geran dan berperanan untuk mengumpulkan modal, melantik kakitangan dan ejen 
bahan mentah untuk pelanggan. Pada tahun 1863, kerajaan Britain telah menukar gelaran Joint Agent General kepada Crown Agents for the Colonies. Dalam konteks NNMB, Crown Agents berperanan penting dalam menguruskan transaksi ekonomi luar negara bagi persekutuan. Hal ini termasuklah juga urusan pembelian barangan dan keperluan jabatan kerajaan, pelantikan kakitangan awam dan ejen yang mendapatkan pinjaman untuk Negeri-Negeri Melayu Bersekutu di pasaran London. CO 717/6 Crown Agents Correspondence, 1920. Lihat juga, Crown Agents, http://www.crownagents.com/about-us/our-history, 2016 (diakses pada 17 Mac 2017) dan Sunderland (2007).

11. Overdraf merupakan tindakan pengeluaran wang daripada institusi kewangan yang melebihi jumlah wang yang disimpan. Keadaan ini menyebabkan pelanggan institusi kewangan tersebut bertanggungjawab terhadap pinjaman jangka pendek daripada bank dan turut dikenakan kadar faedah yang tertentu.

12. Monopoli terhadap eksport bahan mentah dan urusan perbelanjaan tanah jajahan oleh Britain selaku negara induk juga merupakan sebahagian daripada sistem perdagangan merkantilisme yang diamalkan oleh British. Perbincangan lanjut lihat Conti $(2016,6)$.

13. Federated Malay State Annual Report for the Year 1921, hlm. 12.

14. Walaupun begitu, pentadbiran Guillemard melakukan penjimatan anggaran perbelanjaan bagi projek pembangunan di kawasan pelabuhan. Antaranya, projek pembangunan dermaga Prai yang dianggarkan menelan belanja $\$ 8,693,821$ dalam tempoh 1922 hingga 1926, berbanding perbelanjaannya yang tinggi pada tahun 1921 yang bernilai $\$ 13,340,095$. Selain itu, kerajaan NNMB turut mengurangkan anggaran perbelanjaan projek pembangunan landasan keretapi Penang Hill untuk tempoh yang sama kepada $\$ 561,377$ berbanding perbelanjaan tahun 1921 yang menelan belanja bernilai $\$ 738,623$.

15. Legislative Council, Malaya Tribune, 10 August 1921.

16. Pada tahun 1900, Joseph Chamberlain berjaya mendapatkan kepercayaan Parlimen Britain untuk meminda Akta Stok Kolonial. Pindaan pada tahun 1900 telah membolehkan tanah jajahan British kecuali negeri naungan untuk melabur dalam Saham Kolonial. Pindaan terhadap akta ini adalah untuk membolehkan tanah jajahan British mengurangkan beban pinjaman kewangan mereka dalam pasaran London dengan melakukan pinjaman kewangan menerusi sekuriti yang dipegang oleh mereka dalam Saham Kolonial. Lihat Constantine (1984, 15); Trustee Investments in Colonial Stocks, The Singapore Free Press and Mercantile Advertiser, 13 June 1901.

17. CO 717/25, Financial Position, Confidential Correspondence, The Under Secretary of State for the Colonies, 20 January 1922.

18. Dalam penulisannya Ahmad Kamal Ariffin berhujah pinjaman sebanyak $£ 10,000,000$ oleh NNMB ditolak oleh Perbendaharaan Britain disebabkan kemungkinan disebabkan (i) pemilikan pemegang sekuriti saham dalam Saham Kolonial adalah pemilikan kecil, (ii) pengurusan akan dipertanggungjawabkan kepada badan yang dilantik, (iii) perbadanan awam melalui cara ini akan mendapat sokongan kerajaan. Dalam iklim ekonomi yang ditelan kemelesetan, sokongan kerajaan Britain merupakan jaminan yang sangat penting. Lihat Ahmad Kamal (2006, 279). 
19. The Sterling Loan, The Singapore Free Press and Mercantile Advertiser, 4 November 1921.

20. Shorthand Report of the Proceedings of the Federal Council, 3 November 1921. Lihat juga, Federated Malay States, Annual Report for Year 1921, hlm. 7-8.

\section{RUJUKAN}

\section{Sumber Pertama}

CO 717/1. 1920. Colonial Office: Federated Malay States: Original CorrespondenceDespatches.

CO 717/6. 1920. Crown Agents Correspondence.

CO 717/12. 1921. Colonial Office: Federated Malay States: Original Correspondence: Despatches

CO 717/13. 1921. Correspondence from High Commissioner for the Malay States to Winston Churchill, 3 June.

CO 717/25. 1922. Colonial Office: Federated Malay States: Original Correspondence Offices: Miscellaneous.

FCO 141/15978. 1922. F.M.S. Financial Position 1921.

FCO 141/16275. 1932. Note on the Treaty of Federation of Perak, Selangor, Negri Sembilan and Pahang. Signed in July 1895.

Federated Malay States. 1911 a. Proceedings of the Federal Council of the Federated Malay States for the Year 1909-10.

. 1911b. Shorthand report of the Proceedings of the Federal Council, 19 January. 1912. Shorthand report of the Proceedings of the Federal Council, 12 November. 1919. Shorthand Report of the Proceedings of the Federal Council, 25 November. . 1920a. Shorthand Report of the Proceedings of the Federal Council, 19 January. 1920b. Shorthand Report of the Proceedings of the Federal Council, 28 July. 1920c. Shorthand Report of the Proceedings of the Federal Council, 15 September.

. 1921. Annual Report of the Year 1920. Kuala Lumpur: F.M.S. Government Printing.

1921a. Shorthand Report of the Proceedings of the Federal Council, 3 November. . 1921b. Shorthand Report of the Proceedings of the Federal Council, 13 December. 1922. Annual Report for the Year 1921. 1922a. Shorthand Report of the Proceedings of the Federal Council, 19 June. 1922b. Shorthand Report of the Proceedings of the Federal Council, 20 June. . 1922c. Shorthand Report of the Proceedings of the Federal Council, 21 November.

.1922d. Shorthand Report of the Proceedings of the Federal Council, 23 November 1922.

1922e. Supplement to the F.M.S. Government Gazette. 26 August, No. 5327 
1924. Shorthand Report of the Proceedings of the Federal Council. 1925. Federated Malay States Annual Report for the Year 1924. 1926. Annual Report for the Year 1925.

H.C.O. Ch. Sec. 798/1922. 1922. Copy of a minute by the Chief Secretary to Government, 9 November.

H.C.O. 545/1922. 1923. The Final Report of the Retrenchment Commission.

H.M.S.O. 1921. Summary of Proceedings and Documents, Conference of Prime Minister and Representatives of the United Kingdom, The Dominions, and India.

IMR 151/1921. Economy in the Expenditure of the Government Services Appointment of a Retrenchment Committee to Scrutinize the Expenditure.

The Straits Times. 1920. Association of British Malaya, 19 November.

Malaya Tribune. 1921. H.M.S. Malaya Cup, 19 September.

. 1921. Legislative Council, 10 August.

1921. Swettenham Statue, 22 January.

1921. Military Ball, 27 October.

1923. Co-operation in Malaya, 8 August.

The Singapore Free Press and Mercantile Advertiser. 1901. Trustee Investments in Colonial Stocks, 13 June.

1920. Association of British Malaya, 31 August.

1921. The Sterling Loan, 4 November.

1921. Untitle, 12 February.

The Straits Times. 1920. Association of British Malaya, 19 November.

1921. Ceremonies at Brunei, 26 October.

1921. His Majesty's Battleship Malaya, 13 January.

\section{Sumber Kedua}

Ahmad Kamal Arifin Mohd Rus. 1999. Majlis Mesyuarat Persekutuan, 1909-1927: Asas dan kesan pembentukkannya. Malaysia dari Segi Sejarah 27(3): 22-34.

2006. Perkembangan Majlis Mesyuarat Persekutuan, 1909-1927. PhD diss., Jabatan Sejarah, Universiti Malaya.

Ahmad Kamal Ariffin Mohd Rus and Suffian Mansor. 2014. Pengukuhan penguasaan British di Negeri-Negeri Melayu Bersekutu: Analisis dua perjanjian Majlis Mesyuarat Persekutuan, 1909 dan 1927. In Sejarah dan Kesarjanaan, eds. Suffian Mansor, Sivachandralingam Sundara Raja, Arba'iyah Mohd. Nor and Ahmad Kamal Ariffin Mohd. Rus, 1-21. Kuala Lumpur: Jabatan Sejarah Universiti Malaya.

Alvin, C. 2004. The causeway. Singapore: National Library Board. http://eresources.nlb. gov.sg/infopedia/articles/SIP_99_2004-12-30.html (accessed 19 August 2017).

Andaya, B.W. and L.Y. Andaya. 2017. A history of Malaysia. 3rd ed. London: Palgrave.

Belfield, H.C. 1902. Handbook of the Federated Malay States. London: Edward Stanford. Cain, P.J. and A.G. Hopkins. 2014. British imperialism 1688-2015. Oxon: Routledge.

Constantine, S. 1984. The making of British colonial development policy 1914-1940. England: Frank Cass and Company Limited. 
Conti, T.V. 2016. The modern British mercantilist system 1803-1914: Changes in patterns of commerce, industry and warfare. Paper presented at The International Conference "Britain and the World", British Scholar Society. King's College, London, 22-24 June.

Crown Agents. 2016. http://www.crownagents.com/about-us/our-history (accessed 17 March 2017).

Emerson, R. 1974. Malaysia: Satu pengkajian dalam pemerintahan secara langsung dan tidak langsung. Kuala Lumpur: Dewan Bahasa dan Pustaka.

Ghosh, K.K. 1977. Twentieth-century Malaysia: Politics of decentralization of power, 1920-1929. Culcutta: Progressive Publishers.

Lim, T.G. 1977. Peasants and their agricultural economy in colonial Malaya 1874-1941. Kuala Lumpur: Oxford University Press.

Mohd Shazwan Mokhtar. 2017. Perkembangan sistem perdagangan merkantilisme di Negeri-Negeri Melayu Bersekutu, 1909-1925. MA diss., Fakulti Sains Sosial dan Kemanusiaan, Universiti Kebangsaan Malaysia.

Mohd Shazwan Mokhtar, Muhammad Aslah Akmal Azmi and Mohd. Samsudin. 2017. Perkembangan sistem perdagangan merkantilisme Negeri-Negeri Melayu Bersekutu (1909-1913). Jebat: Malaysian Journal of History, Politics \& Strategic Studies 44(2): 1-26.

Sunderland, D. 2007. Managing British colonial and post-colonial development. Woodbridge: The Boydeell Press.

2013. Financing the Raj: The city of London and Colonial India, 1858-1940. Woodbridge: The Boydeell Press.

Swettenham, F. 1906. British Malaya. London: The Bodley Head.

Yeo, K.W. 1971. British policy towards the Malays in the Federated Malay States, 1920 40. PhD diss., Australian National University, Australia. . 1981. The Guillemard-Maxwell power struggle, 1921-1925. Journal of the Malaysian branch of the Royal Asiatic Society 54(1): 48-64. 


\section{LAMPIRAN}

\section{Peta Negeri-Negeri Melayu Bersekutu Pada Tahun 1902}

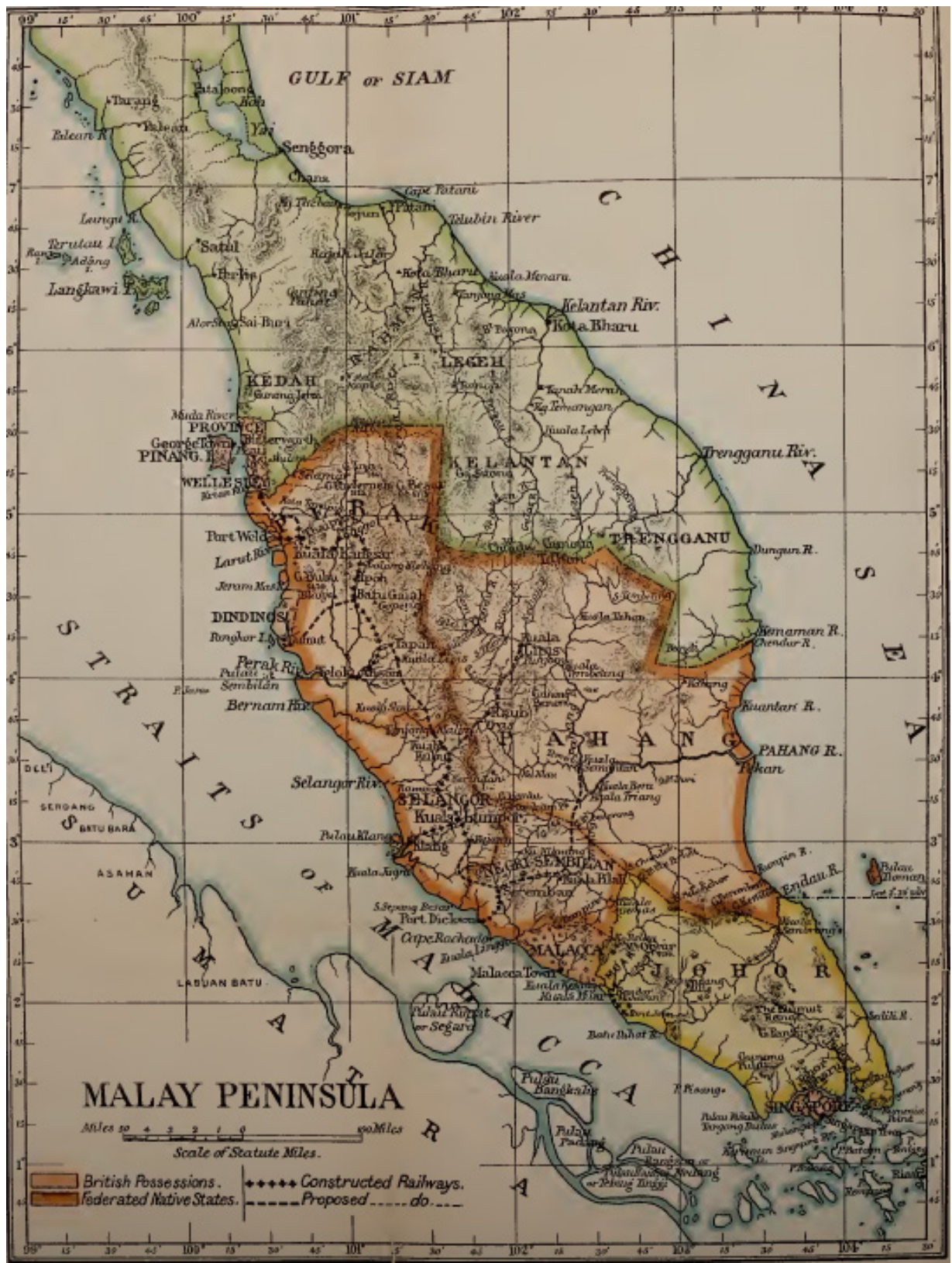

Sumber: Belfield (1902). 